\title{
In situ toxicity testing of Lake Orta sediments
}

\author{
Renato BAUDO*, Daria ROSSI and Monica BELTRAMI \\ CNR Istituto Italiano di Idrobiologia, Largo V. Tonolli 50, 28922 Verbania Pallanza, Italy \\ *e-mail corresponding author: r.baudo@iii.to.cnr.it
}

\begin{abstract}
The use of in situ assays, which was initially proposed by Nebeker et al. (1984), is presently recognised as an effective tool to study the effects of contaminated sediments (Burton 1992). The placement of caged organisms to study short-term effects of exposure to contaminated environments has been employed for a number of aquatic species, both fish and invertebrate. This paper describes the application of this techniques to study the toxicity of Lake Orta sediments using both resident (Daphnia obtusa, D. longispina) and non-resident (D. magna, Echinogammarus stammeri) invertebrate species. In each of the selected stations, a group of four chambers, each containing 10 individuals, were deployed by scuba divers at $10 \mathrm{~m}$ depth and collected after $48 \mathrm{~h}$. For each chamber, the surviving animals were counted, transferred to the laboratory and kept in Lake Orta water until their death. The number of neonates produced by each female in the laboratory was recorded daily in order to determine if the short exposure period could affect the reproductive behaviour of the animals. The technique and results reported here indicate the utility of in situ testing and suggest that, under certain conditions, this method of testing may yield results which are more representative of actual environmental conditions by avoiding the sample manipulation required for traditional laboratory toxicity tests.
\end{abstract}

Keywords: in situ toxicity testing, Lake Orta, Daphnia

\section{INTRODUCTION}

Sediments are generally recognised to play a central role in ecosystem processes, since the sediment surficial layers could be considered to be intimately linked to surface waters through physical, chemical, and biological processes. Studies of aquatic ecosystems should therefore not be limited to the water column, but must also consider the sediment quality and the reactions taking place at the sediment-water interface. This fact has been recognised recently and the integration of chemical, biological and toxicological data has become more commonly used in sediment quality assessment. A commonly cited example of this is the application of the sediment quality triad approach (Long \& Chapman 1985; Chapman 1990; Chapman 1992). Toxicity may be predicted and/or detected in many ways, including through the use of biomarkers; laboratory toxicity tests; QSAR analyses; biological surveys; mesocosms; and mathematical models of ecological structure.

Probably, the most used technique is the traditional toxicity test in the lab, with single or multispecies experiments. A detailed review of the advantages and disadvantages of this approach is beyond the scope of this paper, and interested readers should refer to comprehensive reviews such as those provided by Cairns (1983), Cairns et al. (1992), Landis \& Ho-Yu (1994), and Day et al. (1997). However, standard laboratory toxicity tests do have several limitations, including evaluation of the true extent of their ecological relevance (Day et al. 1997). This issue is related to the fact that exposure conditions may not mimic what occurs in nature, and the organisms are exposed to sediments that have been altered during collection and storage. As a consequence, the toxicity of contaminated sediments transferred to the laboratory may be either greater or less than the toxicity of sediments that are tested in situ (Sasson-Brickson \& Burton 1991; Skalski 1991; Jacher \& Burton 1993). Despite their limitations, in situ assays are presently recognised as an effective tool to study single-species effects of contaminated sediments (Burton 1992), and the placement of caged species to study short-term effects of exposure to contaminated environments has been employed for a number of organisms, including plankton (Munawar et al. 1989), mussels (Metcalfe \& Hayton 1989), zooplankton (Sasson-Brickson \& Burton 1991), leeches (Metcalfe \& Hayton 1989), fish (Hartwell et al. 1987), and amphibians (Linder 1990).

Lake Orta has long been severely impacted by industrial pollution (see other papers in this monograph), and in 1989-1990 the lake was satisfactorily treated with calcium carbonate to neutralise the acidic $\mathrm{pH}$ and to lower the metal concentration in the water column. However, the treatment resulted also in the deposition of toxicants from the water column into the lakebed. Toxicity tests with Vibrio fischeri (Microtox test, 15 min) on pore waters from 10 samples collected in 1992 (Guzzella et al. 1993), indicated that sediments from most of the lake were highly toxic (Fig. 1). A further study (Burton et al. 2000) confirmed that the environment was still toxic for aquatic organisms in 1994. Therefore, as a part of the larger program of study to follow the lake recovery, it was decided to apply in situ techniques to evaluate the potential toxicity of the newly deposited sediments. 


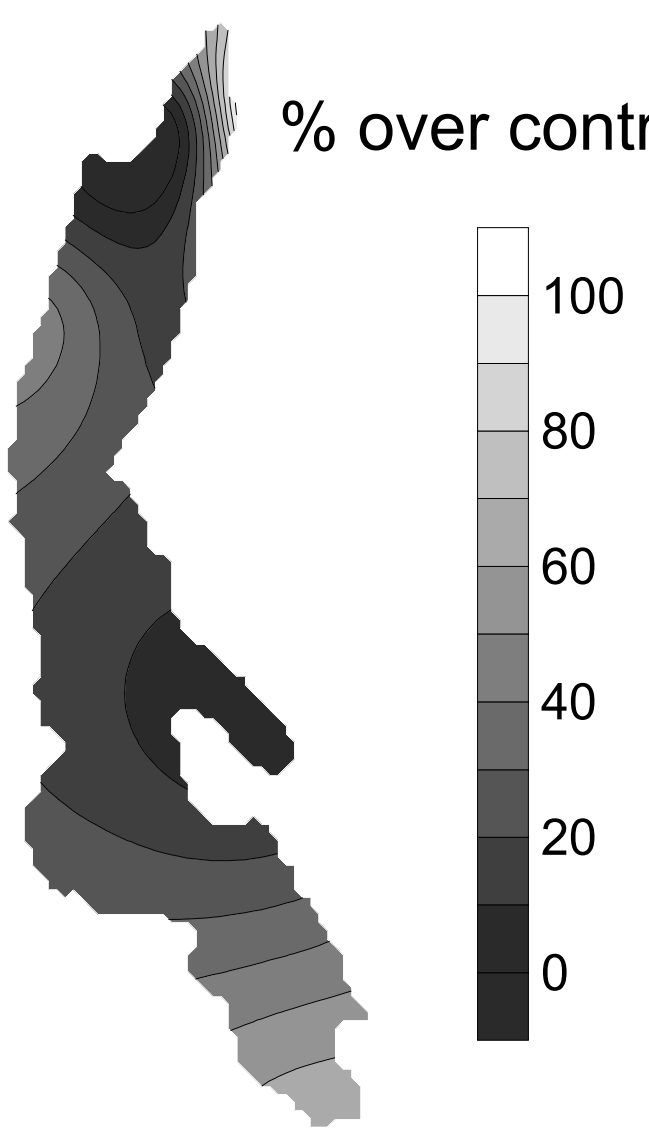

Fig. 1. Inhibition of bioluminescence of Vibrio fischeri (\% luminescence $v s$ controls $=100 \%$ ).

\section{MATERIALS AND METHODS}

In this study, specially devised benthic chambers (Fig. 2) were designed at the Italian Institute of Hydrobiology and manufactured by a commercial workshop (Rossi et al. 1998).

An in situ test vessel consists of a Plexiglas cylinder which is weighted at the bottom by a lead ring imbedded into the Plexiglas (Fig. 2). Both ends of the cylinder are equipped with screened disks, and can be sealed with threaded Plexiglas caps. When positioned onto the sediments by scuba divers, the lead keeps the chamber in a vertical position, while the screens ensure the free flow of water and particles smaller than the mesh size. In the present study the, screens had a nominal pore size of $126 \mu \mathrm{m}$, although different screens could be used depending on the goal of the research. The $126 \mu \mathrm{m}$ net permits exchange by diffusion alone. When a test vessel is filled with deionised water and placed into a water bath containing natural water, the concentration of the solutes inside and outside the chamber becomes homogeneous in less than $60 \mathrm{~min}$. Since the chamber has an inner volume of about $600 \mathrm{ml}$, it can be used to accommodate an adequate number of animals of fairly large size.
Test vessels are prepared for deployment by installing the lower screen and the lower cap, and filling chambers with water. Test organisms are then inserted, and the upper net holder and cap are screwed on, thus sealing the chamber. At the selected station, the scuba divers carry the chambers (4 replicate chambers bound together) to the bottom, then gently remove both upper and lower caps before positioning the chambers onto the sediment.

At the end of the exposure period, the scuba diver replaces the caps before recovering the chamber and carrying it to the support boat. Upon reaching the boat, the upper cap and net holder are removed to permit recovery of the test organisms and the water from the chamber.

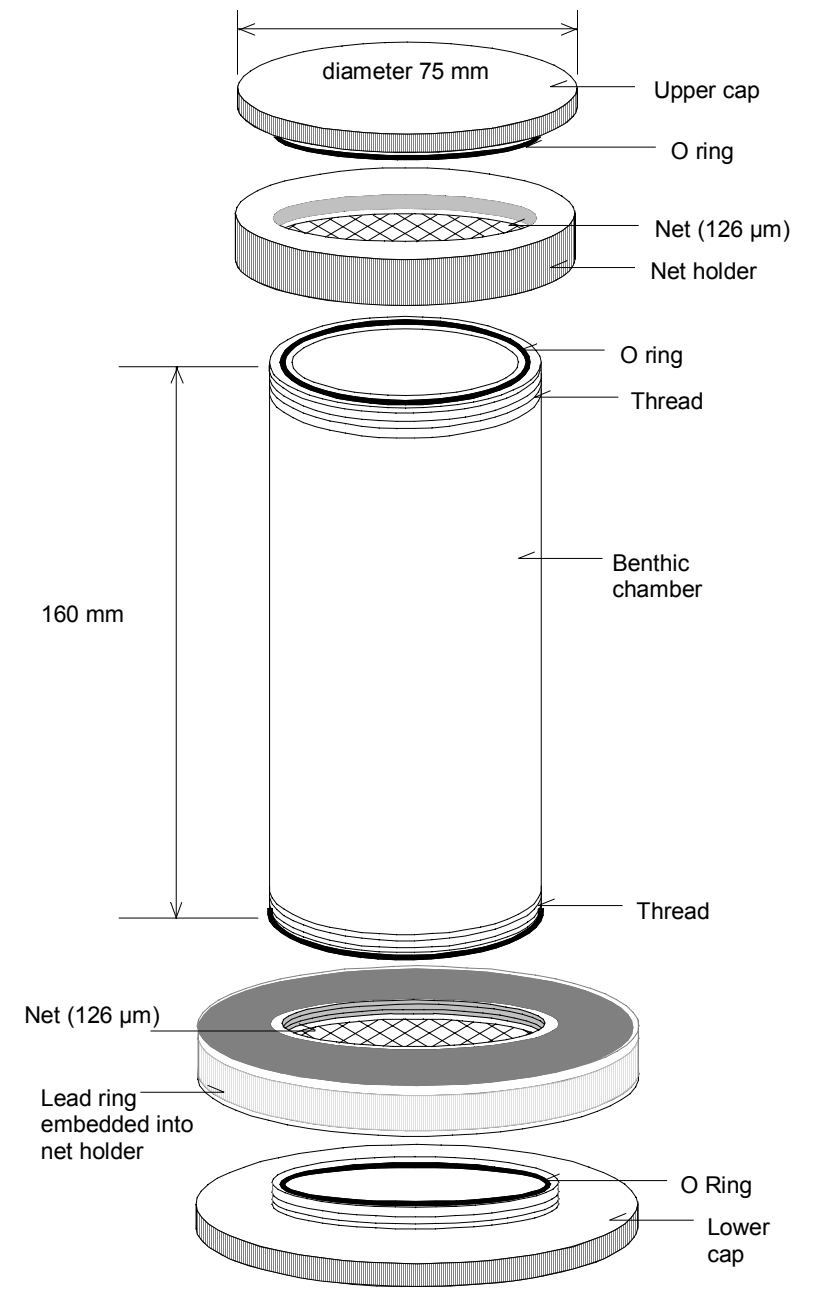

Fig. 2. In situ benthic exposure chamber.

\subsection{In situ toxicity testing}

The toxicity tests began in 1995 and continued till 1998, in different seasons, at the following stations (Fig. 3):

- Station n. 1 (Buccione) and Station 2 (Tortirogno) in October 1995; June 1996; November 1996; Septem- 
ber 1997; July 1998; August 1998; and November 1998;

- Station n. 3 (Omegna) in October 1995. After this time, Station 3 was no longer evaluated, since the positioning of the benthic chambers was extremely difficult on the steep slope, and the rocky substratum prevented the collection of sediment samples.

To account for the missing Station 3, a new station (N. 45) was added in 1997. However, this station is located in the central and deepest part of the lake $(140 \mathrm{~m})$, well beyond the access by scuba divers. Samples of sediment and overlying water from this site were collected by means of a Jenkin gravity corer. In this case, the organisms were exposed to the sediment by placing the benthic chambers within each undisturbed core (3 replicates for each sampling event).

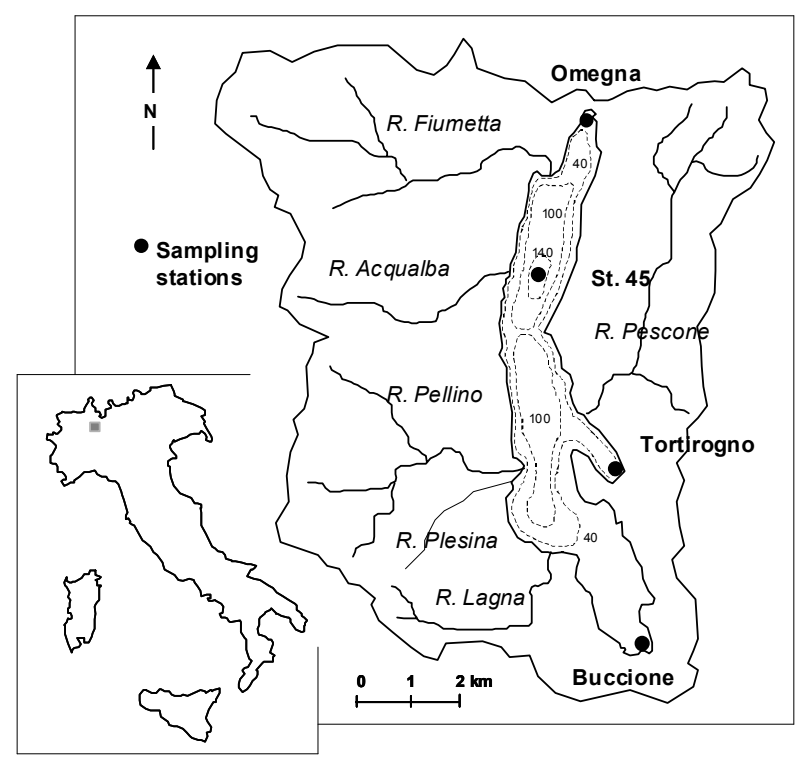

Fig. 3. Sampling stations.

\subsection{Choice of the organisms}

The experiments began with the cladoceran Daphnia obtusa Kurz (Crustacea, Cladocera), which has been present in Lake Orta since at least 1986, before the liming (Bonacina et al. 1988). Specimens were collected from Lake Orta and reared in laboratory in Lake Orta water to provide neonates $(<24 \mathrm{~h}$ old $)$ to be used during the in situ tests.

Since Daphnia obtusa is adapted already to the peculiar chemical conditions of Lake Orta, it is possibly less sensitive to the toxicants present in the sediments. To expand the data set, the non-native amphipod Echinogammarus stammeri (S. Karaman 1931) was also used twice in 1996. The source of the E. stammeri was the River Ticino, and test organisms were reared in Lake Maggiore water according to the procedure given by de March (1981) for Gammarus lacustris lacustris.

In 1997 D. obtusa started to disappear from the lake, so the non-native species Daphnia magna was used in- stead. The D. magna were collected from laboratory cultures, but again reared in Lake Orta water. In 1998, the cladoceran Daphnia longispina O.F. Muller reappeared in Lake Orta. This species has previously been reported as indigenous to the lake (Pavesi 1879; Monti 1929), and D. longispina individuals became increasingly more abundant in our samples. Based on its natural presence, this species was used to continue the in situ toxicity testing.

For the execution of in situ tests, a group of 4 benthic chambers containing test organisms were positioned on the sediments at a depth of $10 \mathrm{~m}$ at each station. The chambers were recovered after $48 \mathrm{~h}$, an exposure period which was selected to avoid the necessity of feeding the test animals. After this time, the benthic chambers were recovered, and the surviving organisms counted, transferred to the laboratory, and kept in Lake Orta water until the death of all test organisms. Laboratory culture conditions included a constant temperature of $20 \pm 1{ }^{\circ} \mathrm{C}$, a photoperiod of $12 \mathrm{~h}$ light and $12 \mathrm{~h}$ dark, and a daily feeding of $10 \mathrm{cal} \mathrm{l}^{-1}$ as suspension of Scenedesmus sp. cells plus yeast. During this period the number of young were recorded daily in order to generate life tables.

For all species of Daphnia, 10 neonates ( $<24 \mathrm{~h}$ old) were placed into each benthic chamber. For E. stammeri, 5 adults were used instead. During all experiments, controls were maintained in Lake Orta water (cladocerans), or in Lake Maggiore water (E. stammeri only), and at a temperature close to that measured at the exposure stations.

Obviously, the biological results obtained from observation of the exposed species in in situ experiments alone does not allow inference of causality, unless further chemical analyses and lab testing can substantiate the causal relationships between ecological response and anthropogenic stressors. Therefore, after recovery of the benthic chambers in 1994, 1995, and 1996, the scuba divers also collected sediment cores from the same locations in order to provide information on the chemical composition of the solid phase. The first 10 $\mathrm{cm}$ of each core were air dried and sieved $(>200 \mu \mathrm{m})$, then macro- and microelements ( $\mathrm{Si}, \mathrm{Al}, \mathrm{Fe}, \mathrm{Ti}, \mathrm{Ca}, \mathrm{K}$, $\mathrm{Mg}, \mathrm{Na}, \mathrm{P}, \mathrm{S}, \mathrm{Pb}, \mathrm{Zn}, \mathrm{Cu}, \mathrm{Ni}, \mathrm{Mn}, \mathrm{Cr}$ ) were determined using X-Ray fluorescence spectrometry.

\section{RESULTS AND DISCUSSION}

The test organisms were reared in Lake Orta water in order to acclimate them to the hydrochemical conditions of the lake. In fact, the routine sampling of Lake Orta plankton regularly showed healthy specimens of $D$. obtusa and, later on, of D. longispina (Bonacina 2001). The lake sediments themselves of course produced a different medium in that sediments contained high concentrations of toxic metals (Tab. 1).

The dynamic equilibrium established at the sediment-water interface, which is controlled by back-diffusion of the soluble species, very likely enhances the 
Tab. 1. Chemical composition of the upper $10 \mathrm{~cm}$ sediment from cores at 4 stations in Lake Orta. Values represent mean concentrations.

\begin{tabular}{lccccccc}
\hline & $\mathrm{Si}(\%)$ & $\mathrm{Al}(\%)$ & $\mathrm{Fe}(\%)$ & $\mathrm{Ca}(\%)$ & $\mathrm{Mg}(\%)$ & $\mathrm{K}(\%)$ & $\mathrm{Ti}(\%)$ \\
\hline Buccione & 28.9 & 8.0 & 4.6 & 0.90 & 1.22 & 2.04 & 0.44 \\
Tortirogno & 27.1 & 9.5 & 4.8 & 0.83 & 1.22 & 2.62 & 0.49 \\
Omegna & 26.6 & 8.4 & 3.6 & 1.65 & 1.70 & 2.71 & 0.40 \\
St. 45 & 22.5 & 7.9 & 8.3 & 0.79 & 1.09 & 1.66 & 0.46
\end{tabular}

\begin{tabular}{lcccccc}
\hline & $\mathrm{S}(\%)$ & $\mathrm{P}(\%)$ & $\mathrm{Na}(\%)$ & $\mathrm{Cl}(\%)$ & $\mathrm{C}(\%)$ & $\mathrm{N}(\%)$ \\
\hline Buccione & 0.55 & 0.16 & 1.32 & $<0.05$ & 8.7 & 1.0 \\
Tortirogno & 0.46 & 0.17 & 1.15 & $<0.05$ & 3.4 & 0.3 \\
$\begin{array}{l}\text { Omegna } \\
\text { St. 45 }\end{array}$ & 0.37 & 0.16 & 1.35 & $<0.05$ & 10.1 & 0.6 \\
& 1.79 & 0.29 & 0.93 & & 12.4 & 1.3 \\
& $\mathrm{~Pb}$ & $\mathrm{Zn}$ & $\mathrm{Cu}$ & $\mathrm{Ni}$ & $\mathrm{Mn}$ & $\mathrm{Cr}$ \\
& $\left(\mathrm{mg} \mathrm{kg}^{-1}\right)$ & $\left(\mathrm{mg} \mathrm{kg}^{-1}\right)$ & $\left(\mathrm{mg} \mathrm{kg}^{-1}\right)$ & $\left(\mathrm{mg} \mathrm{kg}^{-1}\right)$ & $\left(\mathrm{mg} \mathrm{kg}^{-1}\right)$ & $\left(\mathrm{mg} \mathrm{kg}^{-1}\right)$ \\
\hline Buccione & 294 & 458 & 1176 & 113 & 489 & 436 \\
Tortirogno & 311 & 493 & 1273 & 122 & 718 & 485 \\
Omegna & 169 & 479 & 170 & 78 & 740 & 154 \\
St. 45 & 334 & 500 & 1222 & 119 & 1080 & 1769 \\
\hline
\end{tabular}

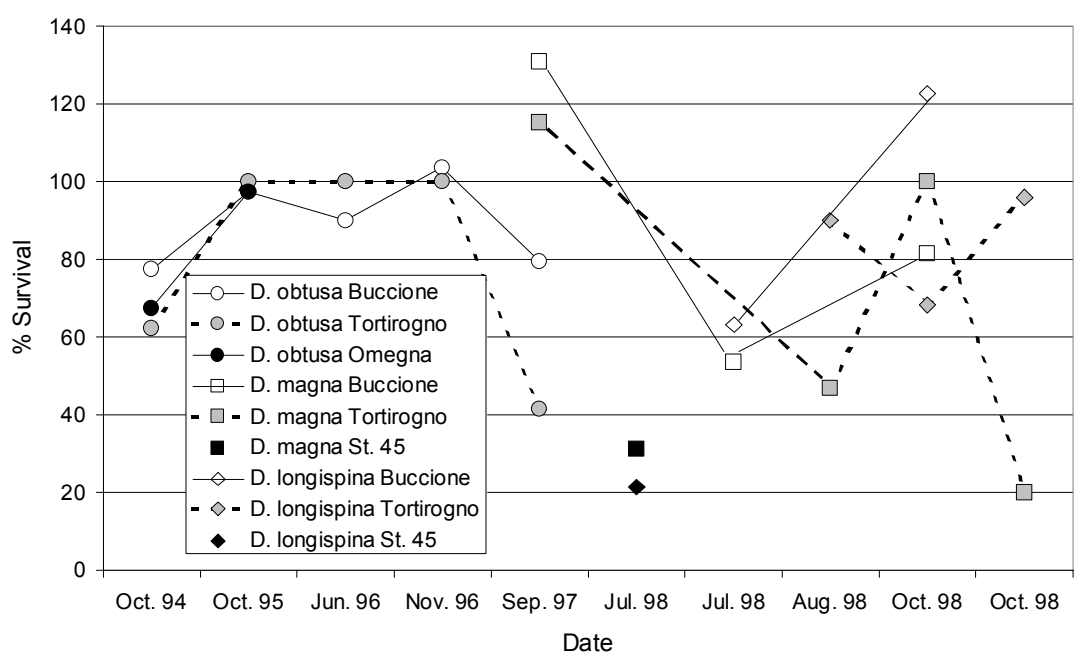

Fig. 4. Survival of test organisms after exposure $(48 \mathrm{~h})$ to Lake Orta sediments. Values represent $\%$ of control survival.

toxicant levels in the water phase with respect to those detected in the water column itself (Calderoni \& Tartari 2001). After $48 \mathrm{~h}$ exposure to sediments collected from Tortirogno in 1994, the survival of D. obtusa was $62.5 \%$ that of organisms in control treatments (Fig. 4). Survival of D. obtusa in sediments collected from Omegna and Buccione in 1994 was $67.5 \%$ and $77.5 \%$ of controls, respectively. The percentage of survivors increased in 1995 and 1996, but dropped again (to 80\% at Buccione and $40 \%$ at Tortirogno) in 1997 . These results may be due to different exposure conditions during the latter experiments, which were performed earlier (September) than the two previous years (October and November). In September 1997 the water temperature was higher $\left(18.6^{\circ} \mathrm{C}\right)$ than in October $1995\left(15.1^{\circ} \mathrm{C}\right)$ or in November $1996\left(12.7^{\circ} \mathrm{C}\right)$. These temperature differences could potentially influence water - sediment exchange and metal toxicity. 1997 was also the year in which $D$. obtusa apparently disappeared from both Buccione and Tortirogno.

In the same experiments, D. magna seemed to respond better, with a survival even greater than that of the controls. In 1998, however, D. magna also displayed relatively high mortality, especially at St. 45 , which has the greatest metal contamination. This station was also the most toxic for D. longispina, whereas Buccione and Tortirogno on average yielded better survival (albeit lower than in controls).

The results of the acute toxicity tests clearly show that sediments at all stations are still relatively toxic, resulting in a decreased survival for the three Daphnia species (Tab. 2). The amphipod Echinogammarus 
Tab. 2. Survival, life expectancy, net reproduction rate, generation length (in $\%$ of control) after in situ exposures of $48 \mathrm{~h}$.

\begin{tabular}{lcccc}
\hline & Survival & Life Expectancy & Net reproduction rate Generation length \\
\hline $\begin{array}{l}\text { D. obtusa } \\
\text { Buccione }\end{array}$ & & & & \\
Tortirogno & 89.6 & 61.0 & 66.1 & 85.8 \\
Omegna & 80.8 & 82.0 & 110.9 & 108.3 \\
Mean & 82.5 & 166.9 & 628.2 & 143.6 \\
D. magna & 84.3 & 103.3 & 268.4 & 112.6 \\
Buccione & & & & \\
Tortirogno & 88.6 & 67.7 & 95.9 & 91.7 \\
St. 45 & 70.5 & 59.9 & 76.6 & 95.7 \\
Mean & 31.0 & 26.4 & 40.0 & 81.2 \\
D. longispina & 63.4 & 51.3 & 70.8 & 89.5 \\
Buccione & & & & \\
Tortirogno & 93.0 & 105.5 & 58.1 & 112.3 \\
St. 45 & 84.7 & 90.7 & 130.5 & 93.6 \\
Mean & 21.4 & 25.3 & 42.4 & 70.3 \\
\hline
\end{tabular}

stammeri, appeared to be much less sensitive in response to sediments collected from both Buccione and Tortirogno in 1996. Survival for E. stammeri exposed to sediments from these sites was identical to control survival, and exposures with this organism were not repeated in subsequent years.

Tab. 3. Life-tables mean values for controls.

\begin{tabular}{lccc}
\hline Control mean & D. obtusa & D. magna & D. longispina \\
\hline $\begin{array}{l}\text { Net reproductive rate } \\
\text { ( } \mathrm{N}^{\circ} \text { newborn) }\end{array}$ & 16.2 & 7.4 & 8.1 \\
$\begin{array}{l}\text { Generation length } \\
\text { (days) }\end{array}$ & 23.8 & 28.8 & 43.2 \\
$\begin{array}{l}\text { Mean exp. Life } \\
\text { (days) }\end{array}$ & 17.1 & 21.7 & 27.9 \\
\hline
\end{tabular}

In addition to direct lethal effect, it is reasonable to expect that exposure of populations to these sediments may elicit negative responses. To test this hypothesis, surviving animals were transferred to Lake Orta water and grown in optimal conditions until the death of the last individual.

Tab. 4. Demographic parameters (in \% with respect to controls) for E. stammeri, after $48 \mathrm{~h}$ exposure to L. Orta sediments. $*$ No neonates produced.

\begin{tabular}{lcc}
\hline & Buccione & Tortirogno \\
\hline June 18, 1996 & & \\
Net reproductive rate & 42 & 10 \\
Generation length & 100 & 100 \\
Mean Life Expectancy & 141 & 227 \\
November 6, 1996 & & \\
Net reproductive rate & $*$ & $*$ \\
Generation length & $*$ & $*$ \\
Mean exp. Life & 54 & 62
\end{tabular}

Demographic parameters were calculated from the resulting life-tables according to procedures suggested by Sieber (1973) and Margalef (1974). These parameters included life expectancy, net reproduction rate, and generation length.

The corresponding values of demographic parameters for controls are reported in table 3 , whereas the results for the different experiments are shown in figures 5-7. Data in figures 5-7 are expressed in \% of control values in order to facilitate comparisons. For all 3 species, the short exposure was sufficient to significantly lower the mean life expectancy (Fig. 5), with the exception of D. obtusa at Omegna. This result, however, refers only to a single test, which was conducted in 1994. St. 45 proved to be the most toxic, reducing by $75 \%$ the life expectancy of both D. magna and D. longispina.

Similar results were also observed for the net reproduction rate (Fig. 6), and for the generation length (Fig. 7), indicating that these demographic parameters were also influenced by maternal exposure to a toxic environment.

For Echinogammarus stammeri (Tab. 4), different results were obtained in June and November. In the first experiment, a significant reduction in the number of neonates was observed, along with longer maternal survival compared to controls. On the other hand, the effects of contaminated sediments was greater in November for E. stammeri. Exposed individuals failed to reproduced and mean life expectancy decreased by $38 \%$ (Tortirogno) and 46\% (Buccione). Therefore, at least for this species, the toxicants present into the sediments did not produce a direct and acute lethal effect, but still affected population parameters to a significant extent. 


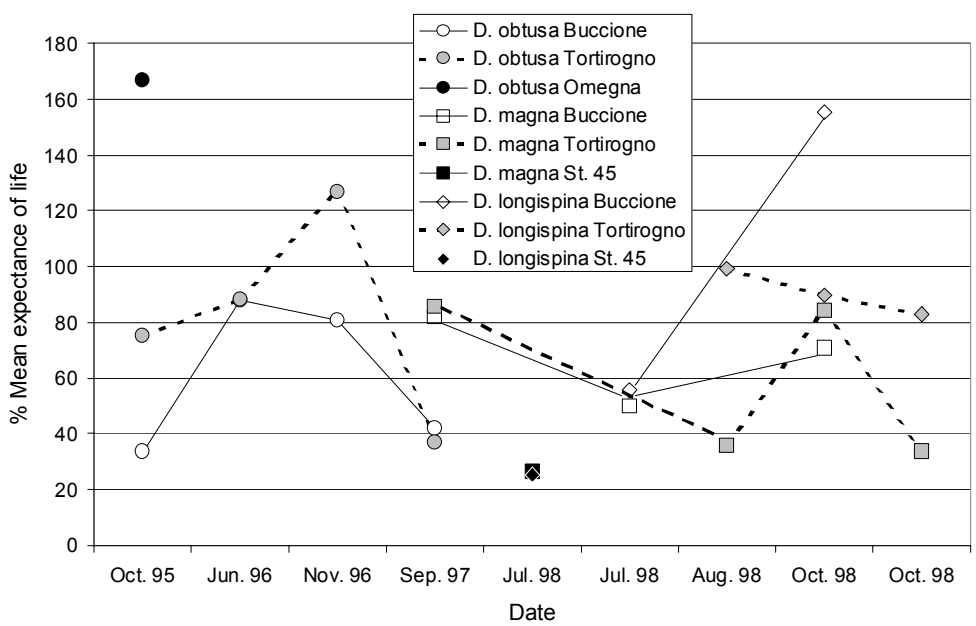

Fig. 5. Mean life expectancy (in \% with respect to the relative controls).

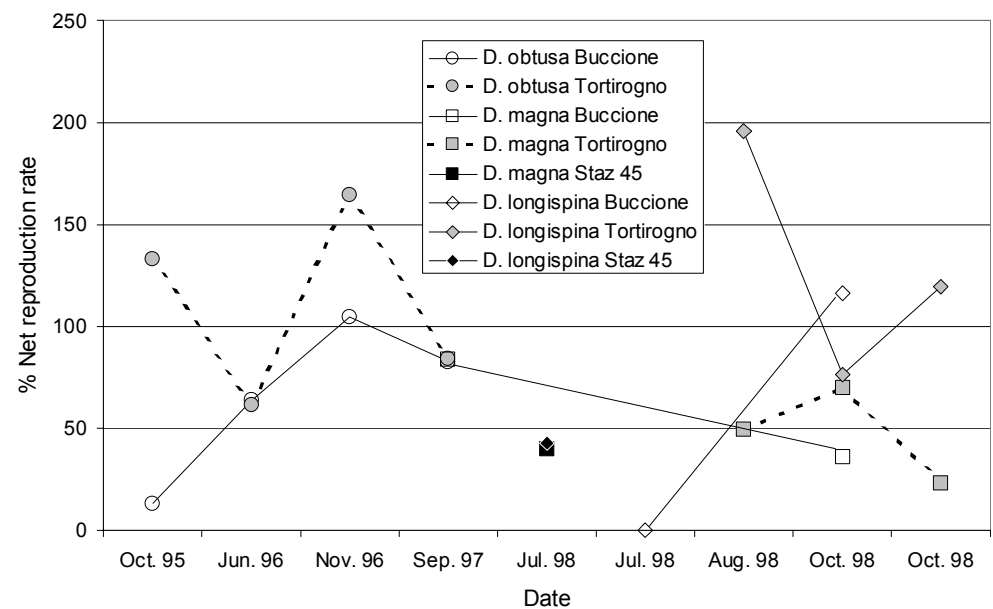

Fig. 6. Net reproduction rate (in \% with respect to the relative controls).

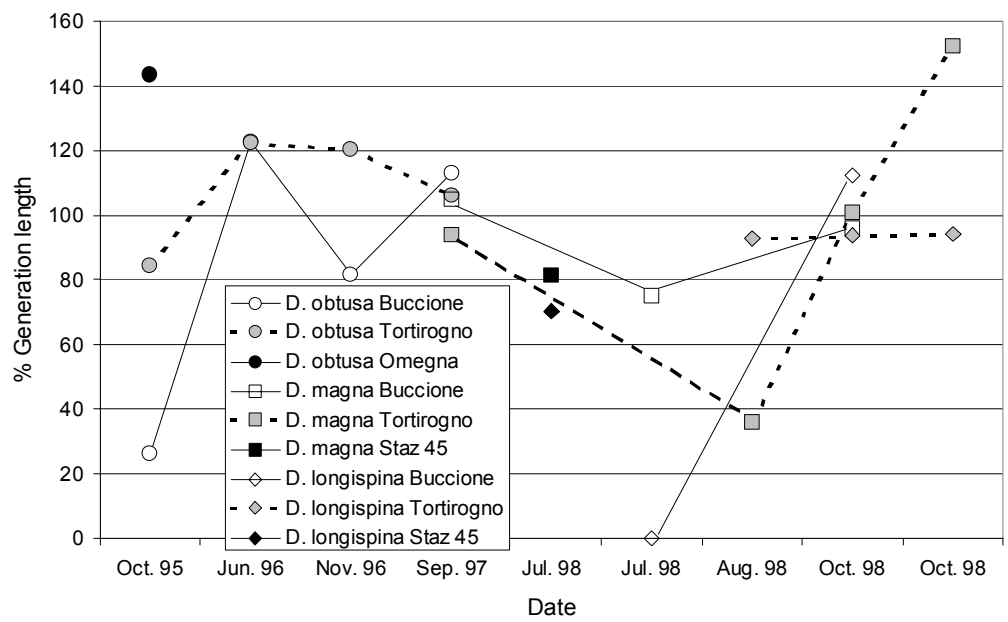

Fig. 7. Generation length (in \% with respect to the relative controls). 


\section{CONCLUSIONS}

As suggested by Ingersoll et al. (1997), "field validation of endpoints is essential to reduce laboratory to field extrapolation error". The in situ approach may be a convenient tool to address this problem, especially as a first step for screening and monitoring polluted environments. At this stage, "the specific identity of the stressor may or may not be important to know (Day et al. 1997)". Only if and when a significant effect is detected should more expensive and time-consuming chemical and ecotoxicological investigations be initiated.

Current research on L. Orta sediments indicates that, after liming, the sediments are still contaminated enough to induce either a direct lethal effect after a short exposure, or sublethal effects influencing population parameters. These effects could potentially affect the whole trophic chain, since they reflect on the population structure of important components of the indigenous zooplankton.

By correlating the results of the tests with information on the chemical composition of cores collected at the same stations, possible causes for the lethal and sublethal effects can be identified. Primary contributors to toxicity appear to be: $\mathrm{Zn}$ (negatively correlated with survival of $D$. obtusa); $\mathrm{Pb}$ (negatively correlated with mean life expectancy and mean generation length in $D$. longispina, and with survival, mean life expectancy, and net reproduction rate in D. magna); Cr (negatively correlated with survival and mean life expectancy in $D$. longispina, and with mean life expectancy in $D$. magna); Mn (negatively correlated with mean generation length in $D$. longispina, and with survival and net reproduction rate in D. magna).

Unfortunately, chemical analyses on the cores did not cover organic micropollutants; but past and ongoing studies (e.g. Guzzella et al. 1993) indicate that PCBs, DDT, and PAHs may reach potentially harmful levels in sediments, at least in the central and northern basins. The toxic effects observed in this study could therefore also be due to such organic contaminants.

The results reported here are consistent with those obtained in toxicity tests with other organisms (Rossi \& Beltrami 1998; Rossi et al. 1998; Beltrami et al. 1999; Burton et al. 2001; Barbero et al. 2001), and it can be concluded that in 1998, 8 years after liming, the sediments of Lake Orta are still contaminated to an extent which can pose some problems for the indigenous biota, possibly delaying the colonisation of the most contaminated areas (Nocentini et al. 2001).

\section{REFERENCES}

Barbero, P., M. Beltrami, R. Baudo \& D. Rossi. 2001. Assessment of Lake Orta sediments phytotoxicity after the liming treatment. J. Limnol., 60(2): 269-276.

Beltrami, M., D. Rossi \& R. Baudo. 1999. Phytoxicity assessment of Lake Orta sediments. Aquatic Ecosystem Health and Management, 2: 391-401.
Bonacina, C. 2001. Lake Orta: the undermining of an ecosystem. J. Limnol., 60(1): 53-59.

Bonacina, C., G. Bonomi, L. Barbanti, R. Mosello \& D. Ruggiu. 1988. Recovery of an industrially acidified, ammonium and heavy metals polluted lake (Lake Orta, N. Italy), due to the adoption of treatment plants. Verh. int. Ver. Limnol., 23: 535-544.

Burton, G.A., Jr. 1992. Plankton, macrophyte, fish, and amphibian toxicity testing of freshwater sediments. In: Burton, G.A., Jr. (Ed.), Sediment Toxicity Assessment. Lewis, Boca Raton An Arbor London Tokyo: 167-182.

Burton, G.A. Jr., R. Baudo, M. Beltrami \& C. Rowland. 2001. Assessing sediment contamination using six toxicity assays. J. Limnol., 60(2): 263-267.

Cairns, J., Jr. 1983. Are single species tocicity tests alone adequate for estimating environmental hazard? Hydrobiologia, 100: 47-57.

Cairns, J., Jr., B.R. Neidelehener \& E.P. Smith. 1992. The emergence of functional attributes as endpoints in ecotoxicology. In: G.A. Burton (Ed.), Sediment toxicity assessment. Lewis, Boca Raton, Florida: 111-128.

Calderoni, A. \& G.A. Tartari. 2001. Evolution of the water chemistry of Lake Orta after liming. J. Limnol., 60(1): 6978.

Chapman, P.M. 1990. The Sediment Quality Triad Approach to Determining Pollution-Induced Degradation. Sci. Tox. Environ., 97-8: 815-825.

Chapman, P.M., E.A. Power \& G.A. Burton. 1992. Integrative Assessments in Aquatic Ecosystems. In: G.A. Burton (Ed.), Sediment Toxicity Assessment. Lewis Publ., Ann Arbor Boca Raton London Tokyo: 313-340.

Day, K.E., W.E. Clements, T. DeWitt, W.G. Landis, P. Landrum, D.J. Morrisey, M. Reiley, D.M. Rosenberg \& G.W. Suter, II. 1997. Workgroup summary report on critical issues of ecological relevance in sediment risk assessment. In: C.G. Ingersoll, T. Dillon \& G.R. Biddinger (Eds), Ecological risk assessments of contaminated sediments. Proc. Pellston Workshop on Sediment Ecological Risk Assessment, 23-28 April 1995. Pacific Grove, California. SETAC Special Publ. Series, SETAC Press, Pensacola, Florida. Chapter 12: 167-198.

de March, B.G.E. 1981. Gammarus lacustris lacustris G.O. Sars. In: S.G. Lawrence (Ed.), Manual for the culture of selected freshwater invertebrates. Department of Fisheries and Oceans. Canadian Special Publication of Fisheries and Aquatic Sciences 54, Ottawa: 79-94.

Guzzella, L., P. Ross, C. Bartone \& R. Baudo. 1993. Toxicity identification evaluation of Lake Orta sediments. I SETAC World Congr. Ecotoxicology and Environmental Chemistry - a Global Perspective. Lisbon, Portugal, March 28-31, 1993. Abstract Book: abstr. 108.

Hartwell, S.I., D.S. Cherry \& J. Cairns, Jr. 1987. Field validation of avoidance of elevated metals by fathead minnows (Pimephales promelas) following in situ acclimation. Environ. Toxicol. Chem., 6: 189-200.

Ingersoll, C.G., G.T. Ankley, R. Baudo, G.A. Burton, W. Lick, S.N. Luoma, D.D. MacDonald, T.B. Reynoldson, K.R. Solomon, R.C. Swartz \& W.J. Warren-Hicks. 1997. Workshop summary report on uncertainty evaluation of measurement endpoints used in sediment ecological risk assessment. In: C.G. Ingersoll, T. Dillon \& G.R. Biddinger (Eds), Ecological risk assessments of contaminated sediments. Proc. Pellston Workshop on Sediment Ecological Risk Assessment, 23-28 April 1995. Pacific Grove, California. SETAC Special Publ. Series, SETAC Press, Pensacola, Florida. Chapter 18: 297-352.

Jacher, K.A. \& G.A. Burton, Jr. 1993. In situ toxicity assessment on nonpoint source runoff using the freshwater amphipod Hyalella azteca. Poster Pres. $14^{\text {th }}$ Ann. SETAC Meet., Houston, TX, November 14-18. 
Landis, W.G. \& M. Ho-Yu. 1994. An introduction to environmental toxicology: impacts of chemicals on ecological systems. Lewis, Boca Raton, Florida.

Linder, G. 1990. Laboratory and in situ toxicity testing with amphibians. Abstr. Ann. SETAC Meet., P220, Arlington, VA: 169.

Long, E.R. \& P.M. Chapman. 1985. A Sediment Quality Triad: measures of sediment contamination, toxicity and infaunal community composition in Puget Sound. Mar. Pollut. Bull., 16: 405-415.

Margalef, R. 1974. Ecologia. Ediciones Omega, S.A., Barcelona: $951 \mathrm{pp}$.

Metcalfe, J.L. \& A. Hayton. 1989. Comparison of leeches and mussels as biomonitors for chlorophenol pollution. $J$. Great Lakes Res., 15: 654-668.

Monti, R. 1929. La limnologia comparata dei laghi insubrici. Verh. int. Ver. Limnol., 4: 462-497.

Munawar, M., I.F. Munawar \& G.G. Leppard. 1989. Early warning assays: An overview of toxicity testing with phytoplankton in the North American Great Lakes. Hydrobiologia, 188/189: 237-246.

Nebeker, A.V., M.A. Cairns, J.H. Gakstatter, K.W. Malueg, G.S. Schuytema and D.F. Krawczyk. 1984. Biological methods for determining toxicity of contaminated fresh- water sediments to invertebrates. Environ. Toxicol. Chem., 3: 617-630.

Nocentini, A.M., A. Boggero, G. De Margaritis \& M. Gianatti. 2001. First phase of macroinvertebrate repopulation of Lake Orta (Buccione Basin) after liming. J. Limnol., 60(1): 110-126.

Pavesi, P. 1879. Nuova serie di ricerche sulla fauna pelagica dei laghi italiani. Rend. R. Ist. Lomb. Sc. Lett., Serie II, 12: 474-483.

Rossi, D. \& M. Beltrami. 1998. Sediment ecological risk assessment: in situ and laboratory toxicity testing of Lake Orta sediments. Chemosphere, 37: 2885-2894.

Rossi, D., R. Baudo, M. Beltrami, M. Contesini \& A. Pranzo. 1998. Valutazione della tossicità dei sedimenti del Lago d'Orta mediante esposizione di organismi in situ e test di laboratorio. Acqua Aria, 98/6: 105-114.

Sasson-Brickson, G. \& G.A. Burton. 1991. In situ and laboratory sediment toxicity testing with Ceriodaphnia dubia. Environ. Toxicol. Chem., 10: 201-207.

Sieber, G.A.F. 1973. The estimation of animal abundance and related parameters. Griffin, London: $506 \mathrm{pp}$

Skalski, J. 1991. Laboratory and in situ sediment toxicity evaluation on early life stages of Pimephales promelas. $\mathrm{MSc}$ thesis, Wright State Univ., $\mathrm{OH}$. 